\title{
NEW DESIGN OF STILLING BASIN MODEL WITH SQUARE SILL
}

\author{
H.L.Tiwari ${ }^{1}$, V.K.Gahlot ${ }^{2}$, Arun Goel ${ }^{3}$ \&, Bikram Prasad ${ }^{4}$ \\ ${ }^{1}$ Department of Civil Engineering, Maulana Azad National Institute of Technology, Bhopal, India \\ ${ }^{2}$ Department of Civil Engineering, Maulana Azad National Institute of Technology, Bhopal, India \\ ${ }^{3}$ Department of Civil Engineering, NIT Kurukshetra \\ ${ }^{4}$ Department of Civil Engineering, Maulana Azad National Institute of Technology, Bhopal, India
}

\begin{abstract}
Sustainable irrigation management system required efficient and economical design of stilling basin .The stilling basins are used to dissipate the energy of flowing water and protect the downstream structures like spillways, canals, etc. from the scouring. The aim of the present experimental investigation is to design the new stilling basin models for non circular pipe outlet using intermediate sill of square cross section. Performance of new stilling basin models were determined with performance index (PI), by operating the constant test run time of one hour and same base material downstream end sill. Increased values of PI indicate better performance of the stilling basin model. After experimentation with thirty test runs, it was found that when intermediate sill of square cross section is placed in suitable location in the stilling basin model, performance of basin improved significantly as compared to USBR VI impact basin model
\end{abstract}

Keywords: Energy, Froude number, Stilling- basin, Scouring, USBRVI.

$* * *$

\section{INTRODUCTION}

Stilling basin with appurtenances like impact wall, intermediate sill, end sill, etc. can be used effectively in reducing the excessive energy of flowing water downstream of hydraulic structure like over flow spillway, sluices, pipe outlets, etc. Different types of recommended stilling basin models for pipe outlets are by Bradely and Peterka (1957), Fiala and Maurice(1961), Keim (1962), Flammer et al. (1970), Vollmer and Khader (1971), Verma and Goel (2000 \& 2003), Goel (2008), Tiwari et al. (2011, 2012 \&2013), Tiwari and Gahlot (2012), Tiwari (2013 \& 2013) Tiwari\& Goel(2015). Appurtenances with proper design and suitable location play an important role for the protection of downstream hydraulic structures by reducing the kinetic energy of flowing water in the stilling basin. A stilling basin for a pipe outlet consists of appurtenances like splitter block, impact wall, intermediate sill and an end sill etc. The present research paper investigates the effect of intermediate sill of square cross section with end sill along with impact wall in stilling basin on scour pattern downstream of the basin which includes the maximum depth of scour and its distance from end sill, etc. The jet of issuing water strikes upon the vertical hanging wall, which spreads the flow of water equally over the full channel width. The flow moved towards the upper part of the impact wall and comes down on the floor of stilling basin after striking the hood portion of hanging wall. The end sill is a terminal element in the basin, which has a great contribution to promote the reduction of energy of flowing water and assists to improve the flow pattern downstream of the channel, thereby helps in reducing the length of stilling basin also. The sill height, configuration and position have great impact on the dissipation of energy of flowing water (Tiwari 2012).

\section{MATERIALS AND METHODS}

\subsection{Programme Experimental}

The experiments were conducted in a recirculating laboratory flume of $0.95 \mathrm{~m}$ wide $1 \mathrm{~m}$ deep and $25 \mathrm{~m}$ long. A rectangular pipe having cross section as $10.8 \mathrm{~cm}$. x $6.3 \mathrm{~cm}$. and $5.75 \mathrm{~m}$ long was used as the pipe outlet. This pipe was connected with delivery pipe of the centrifugal pump. The exit of pipe was kept above stilling basin by one equivalent diameter $(\mathrm{d}=9.3 \mathrm{~cm})$. A wooden floor was provided downstream of the outlet for fixing the appurtenances in the basin. To observe the scour after the end sill of stilling basin, sand bed having properties as given in Table 2 was used. The discharge was measured by a calibrated venturimeter fitted in to the delivery pipe. The desired steady flow condition with normal depth was maintained with the operation of tail gate. After one hour test run, the motor was switched off. The value of maximum depth of scour $\left(d_{m}\right)$ and its location from the end sill $\left(d_{s}\right)$ were noted and performance of the models was evaluated by computing the values of performance index. Higher values of PI represent better performance as compared to the model producing lower values of performance index. All the testing were performed for constant running time of one hour and with the same sand bed for three Froude numbers i.e., 3.85, 2.85 and 1.85. Arrangements of models are given in Tables 1 and also shown in Figures 1, 2, 3,4\&5.

\section{SCHEME OF EXPERIMENTATION}

Testing of models consisting of the best impact wall of size $1.5 \mathrm{~d} \times 3 \mathrm{~d}$ and square intermediate sill (IS) of size $\mathrm{d} / 2 \times \mathrm{d} / 2$ along with the end sill experimented with the variation of location of impact wall and square intermediate sill to evaluate the performance of basin models. First of USBR VI model(MSM-6) was tested then length of basin was 
reduced to $7 \mathrm{~d}$ and appurtenances like new impact wall and square intermediate sill were introduced. In model MSM46 , impact wall placed at $4 \mathrm{~d}$ and IS placed it $3 \mathrm{~d}$ along with the sloping end sill fixed at 7d. In model MSM-47, MSM48 , intermediate sill was varied at $2 \mathrm{~d}$ and $5 \mathrm{~d}$, keeping impact wall at $4 \mathrm{~d}$. In model MSM-49, testing was performed by keeping the impact wall at $2 \mathrm{~d}$ and intermediate sill at $3 \mathrm{~d}$. MSM-50 was performed by varying intermediate sill at $4 \mathrm{~d}$ and the impact wall was kept at 2d. In models, MSM-51 and MSM-52, position of the impact wall was fixed at $3 \mathrm{~d}$ and location of intermediate sill was varied to $4 \mathrm{~d}$ and $5 \mathrm{~d}$ respectively. Finally, model was tested with keeping the impact wall at $5 \mathrm{~d}$ and intermediate sill (IS) at $4 \mathrm{~d}$ and named as MSM-53. All these models are shown in Figures $1,2,3,4 \& 5$ and also illustrated in tabular form in Table 1.

Table 1 Scheme of Experimentation

\begin{tabular}{|l|l|l|l|l|l|l|l|l|}
\hline \multirow{2}{*}{$\begin{array}{l}\text { S. } \\
\text { No. }\end{array}$} & \multirow{2}{*}{$\begin{array}{l}\text { Model } \\
\text { Name }\end{array}$} & Size & $\begin{array}{l}\text { Bottom gap } \\
\text { with basin } \\
\text { floor }\end{array}$ & $\begin{array}{l}\text { Location } \\
\text { from outlet } \\
\text { exit }\end{array}$ & Shape & Height & Width & $\begin{array}{l}\text { Location } \\
\text { from outlet } \\
\text { exit }\end{array}$ \\
\hline 1 & MSM6 & $1 \mathrm{~d} \times 2.2 \mathrm{~d}$ & $1 \mathrm{~d}$ & $3 \mathrm{~d}$ & - & - & - & - \\
\hline 2 & $\mathrm{MSM}-42$ & $1.5 \mathrm{~d} \times 3 \mathrm{~d}$ & $1 \mathrm{~d}$ & $4 \mathrm{~d}$ & - & - & - & - \\
\hline 3 & $\mathrm{MSM}-46$ & $1.5 \mathrm{~d} \times 3 \mathrm{~d}$ & $1 \mathrm{~d}$ & $4 \mathrm{~d}$ & Square & $\mathrm{d} / 2$ & $\mathrm{~d} / 2$ & $3 \mathrm{~d}$ \\
\hline 4 & $\mathrm{MSM}-47$ & $1.5 \mathrm{~d} \times 3 \mathrm{~d}$ & $1 \mathrm{~d}$ & $4 \mathrm{~d}$ & Square & $\mathrm{d} / 2$ & $\mathrm{~d} / 2$ & $2 \mathrm{~d}$ \\
\hline 5 & $\mathrm{MSM}-48$ & $1.5 \mathrm{~d} \times 3 \mathrm{~d}$ & $1 \mathrm{~d}$ & $4 \mathrm{~d}$ & Square & $\mathrm{d} / 2$ & $\mathrm{~d} / 2$ & $5 \mathrm{~d}$ \\
\hline 6 & $\mathrm{MSM}-49$ & $1.5 \mathrm{~d} \times 3 \mathrm{~d}$ & $1 \mathrm{~d}$ & $2 \mathrm{~d}$ & Square & $\mathrm{d} / 2$ & $\mathrm{~d} / 2$ & $3 \mathrm{~d}$ \\
\hline 7 & $\mathrm{MSM}-50$ & $1.5 \mathrm{~d} \times 3 \mathrm{~d}$ & $1 \mathrm{~d}$ & $2 \mathrm{~d}$ & Square & $\mathrm{d} / 2$ & $\mathrm{~d} / 2$ & $4 \mathrm{~d}$ \\
\hline 8 & $\mathrm{MSM}-51$ & $1.5 \mathrm{~d} \times 3 \mathrm{~d}$ & $1 \mathrm{~d}$ & $3 \mathrm{~d}$ & Square & $\mathrm{d} / 2$ & $\mathrm{~d} / 2$ & $4 \mathrm{~d}$ \\
\hline 9 & $\mathrm{MSM}-52$ & $1.5 \mathrm{~d} \times 3 \mathrm{~d}$ & $1 \mathrm{~d}$ & $3 \mathrm{~d}$ & Square & $\mathrm{d} / 2$ & $\mathrm{~d} / 2$ & $5 \mathrm{~d}$ \\
\hline 10 & $\mathrm{MSM}-53$ & $1.5 \mathrm{~d} \times 3 \mathrm{~d}$ & $1 \mathrm{~d}$ & $5 \mathrm{~d}$ & Square & $\mathrm{d} / 2$ & $\mathrm{~d} / 2$ & $4 \mathrm{~d}$ \\
\hline
\end{tabular}

\section{PERFORMANCE EVALUATION}

The performance of a stilling basin models tested for different Froude number (Fr) is a function of channel velocity $(\mathrm{v})$, the maximum depth of scour $\left(\mathrm{d}_{\mathrm{m}}\right)$ and its location from end sill $\left(\mathrm{d}_{\mathrm{s}}\right)$. A stilling basin model having smaller depth of scour at a longer distance is considered to have a better performance as compared to another stilling basin which results in a larger depth of scour at a shorter distance when tested under similar flow condition (Verma \& Goel 2003). A new non dimensional number, called as performance index (PI) has been used for comparison of performance of stilling basin model (Tiwari et al. 2011). This is given as below

$$
P I=\frac{\operatorname{Vxd}_{\mathrm{s}}}{2 \mathrm{~d}_{\mathrm{m}} \sqrt{\mathrm{g} \frac{\rho_{\mathrm{s}}-\rho_{\mathrm{w}}}{\rho_{\mathrm{w}}} d_{50}}}
$$

Where, V - the mean velocity of channel, $d_{s}$ - distance of maximum depth of scour from end sill, $\mathrm{d}_{\mathrm{m}^{-}}$depth of maximum scour, $g$ - gravitation acceleration, $\boldsymbol{\rho}_{\mathrm{s}}$ - density of sand, $\boldsymbol{\rho}_{\mathbf{w}}$ density of water, $\mathrm{d}_{50^{-}}$the particle size such that $50 \%$ of the sand particle is finer than this size, A higher value of performance index indicates a better performance of the stilling basin model. This performance index takes into consideration of flow, scour parameters $\left(\mathrm{d}_{\mathrm{m}} \& \mathrm{~d}_{\mathrm{s}}\right)$ and properties of material used in the basin. The value of Performance index for various runs for each model at different Froude numbers are given in Table 2.

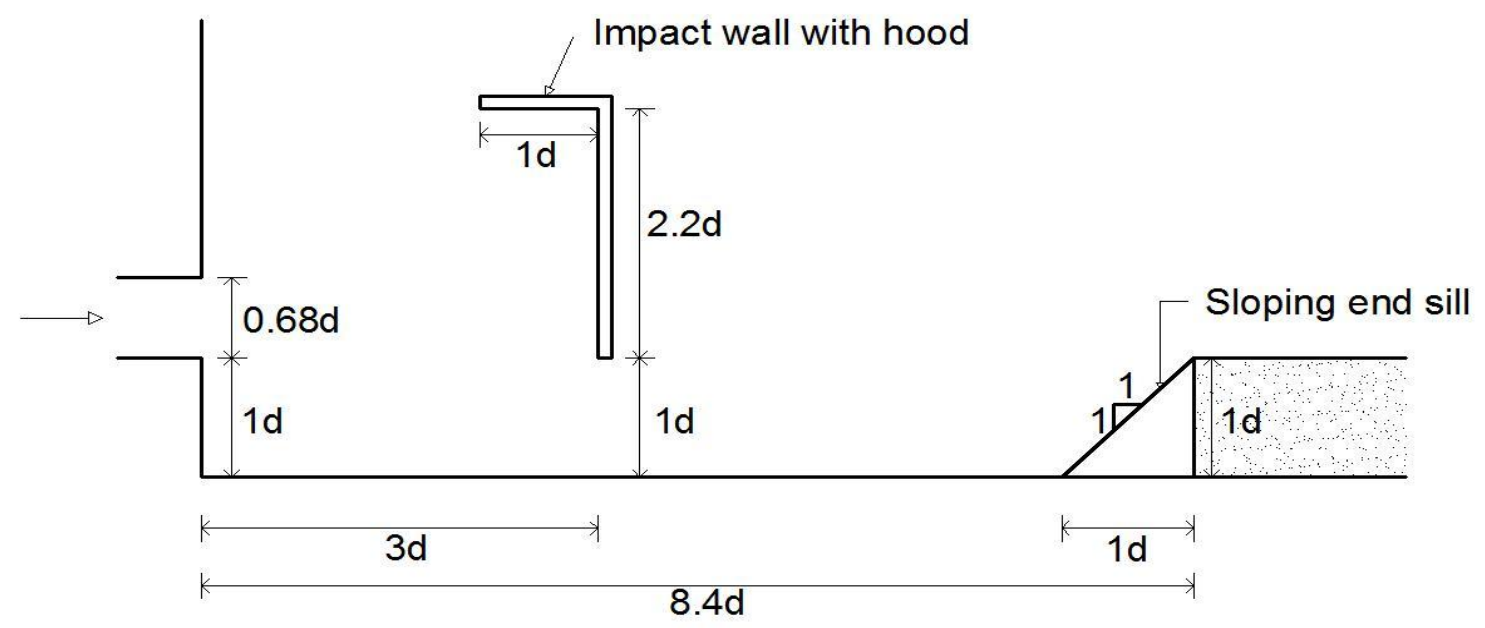

Fig 1 USBR VI model with Impact Wall and End Sill (Model MSM-6) at8.4d length 


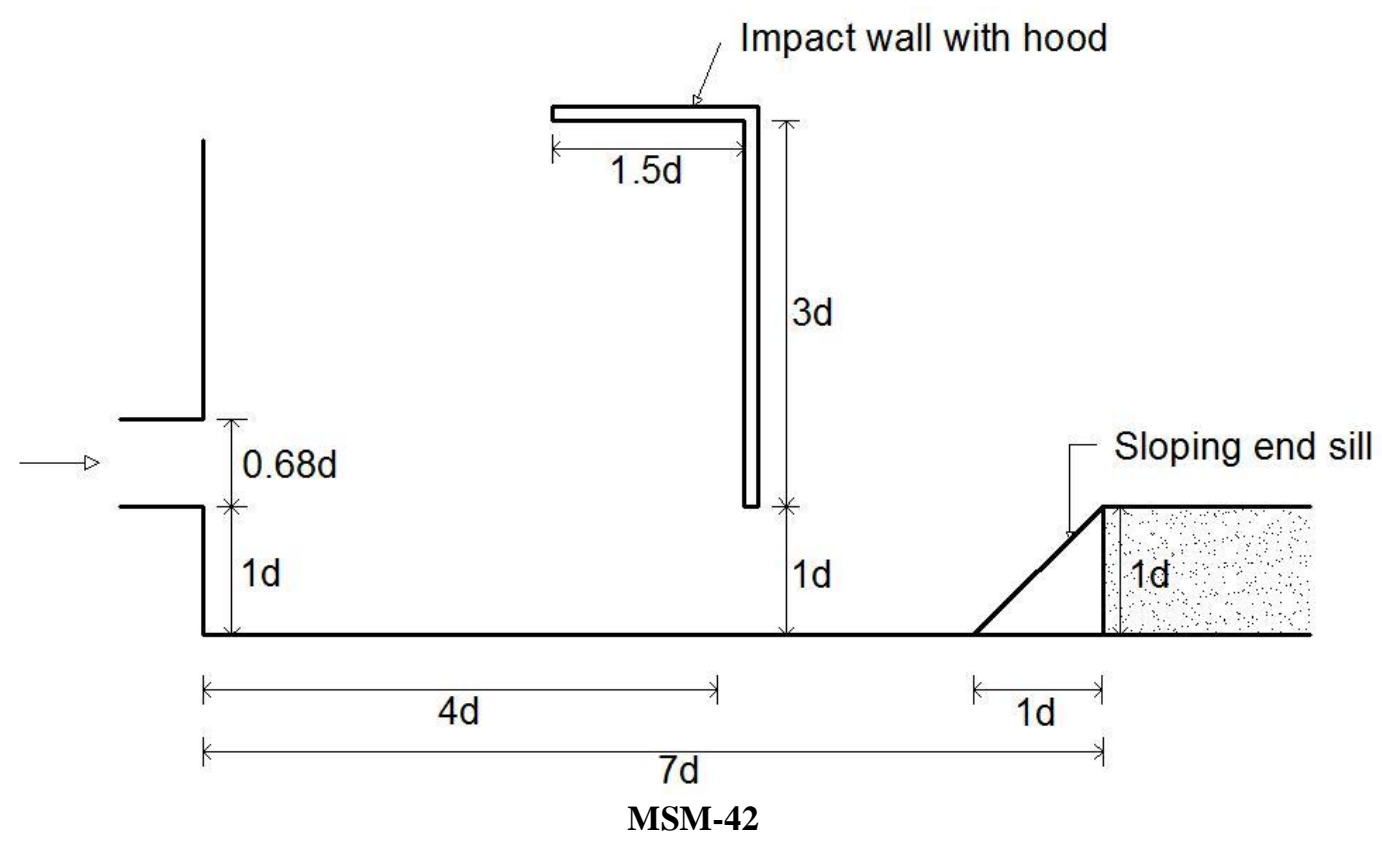

Figure 2 Model MSM-42 with Impact Wall and End Sill at Basin Length 7d

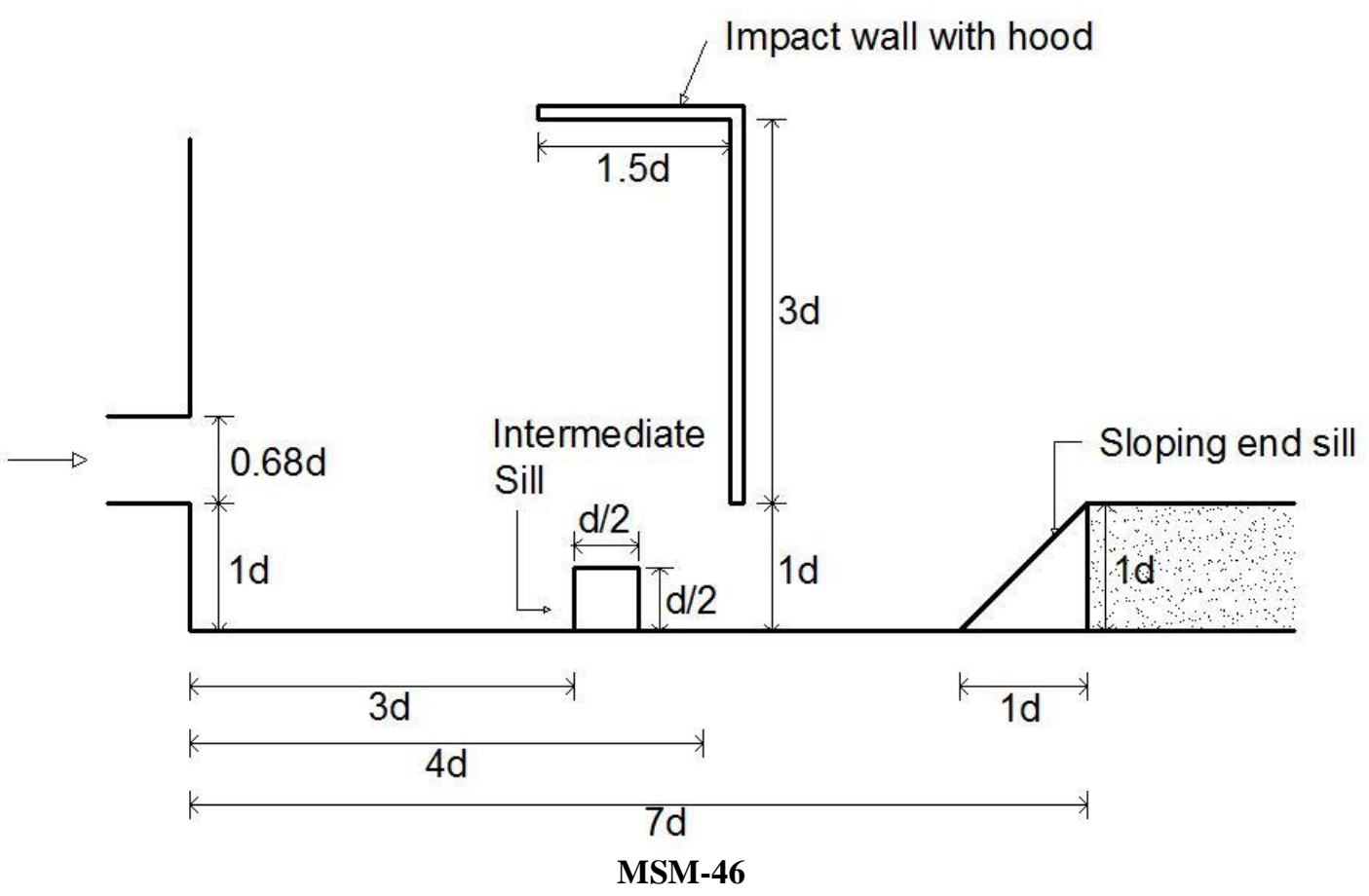




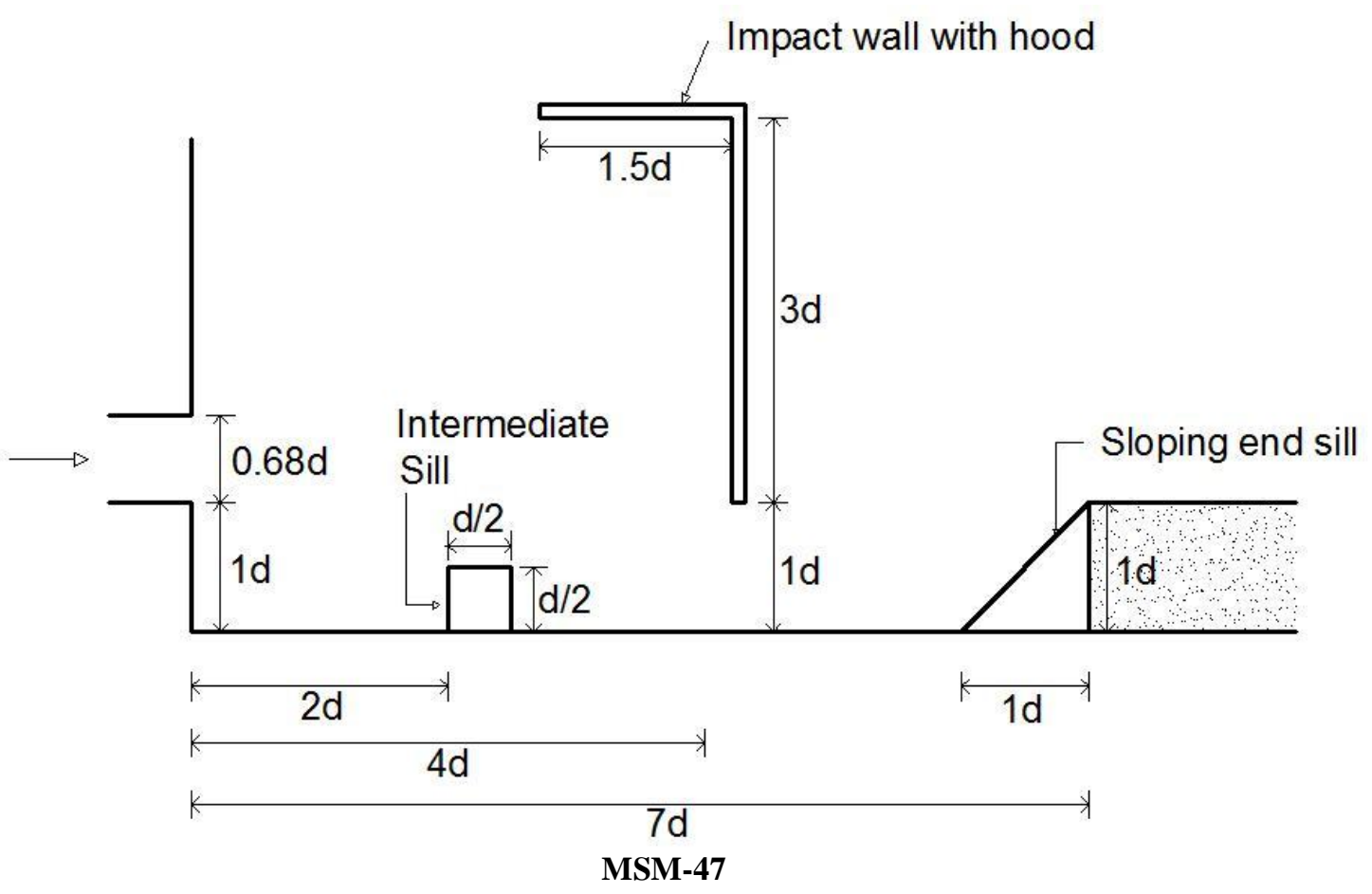

Fig 3 Models (MSM-46 to MSM-47) with Intermediate Sill along with Impact Wall and End Sill at Basin Length 7d

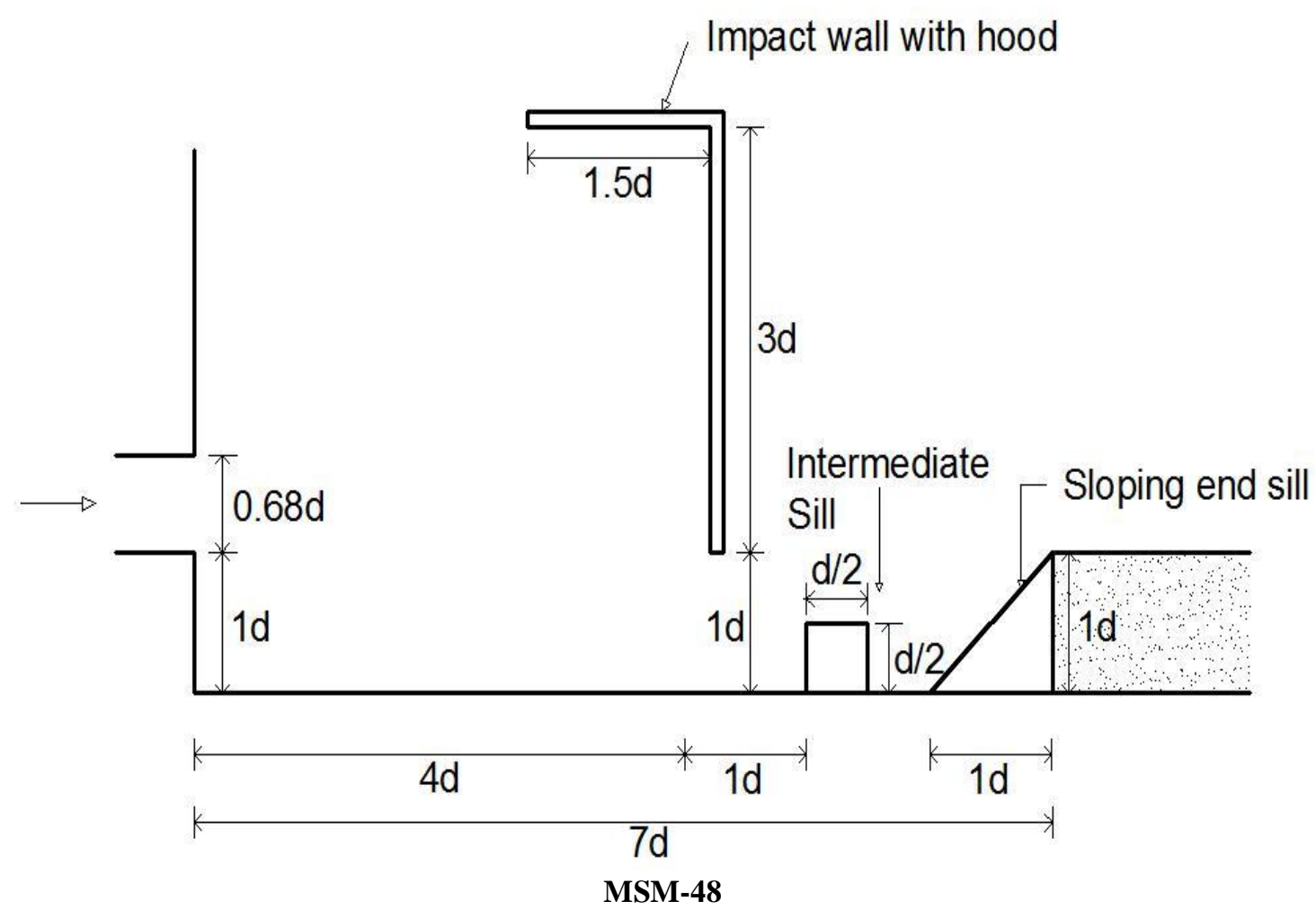




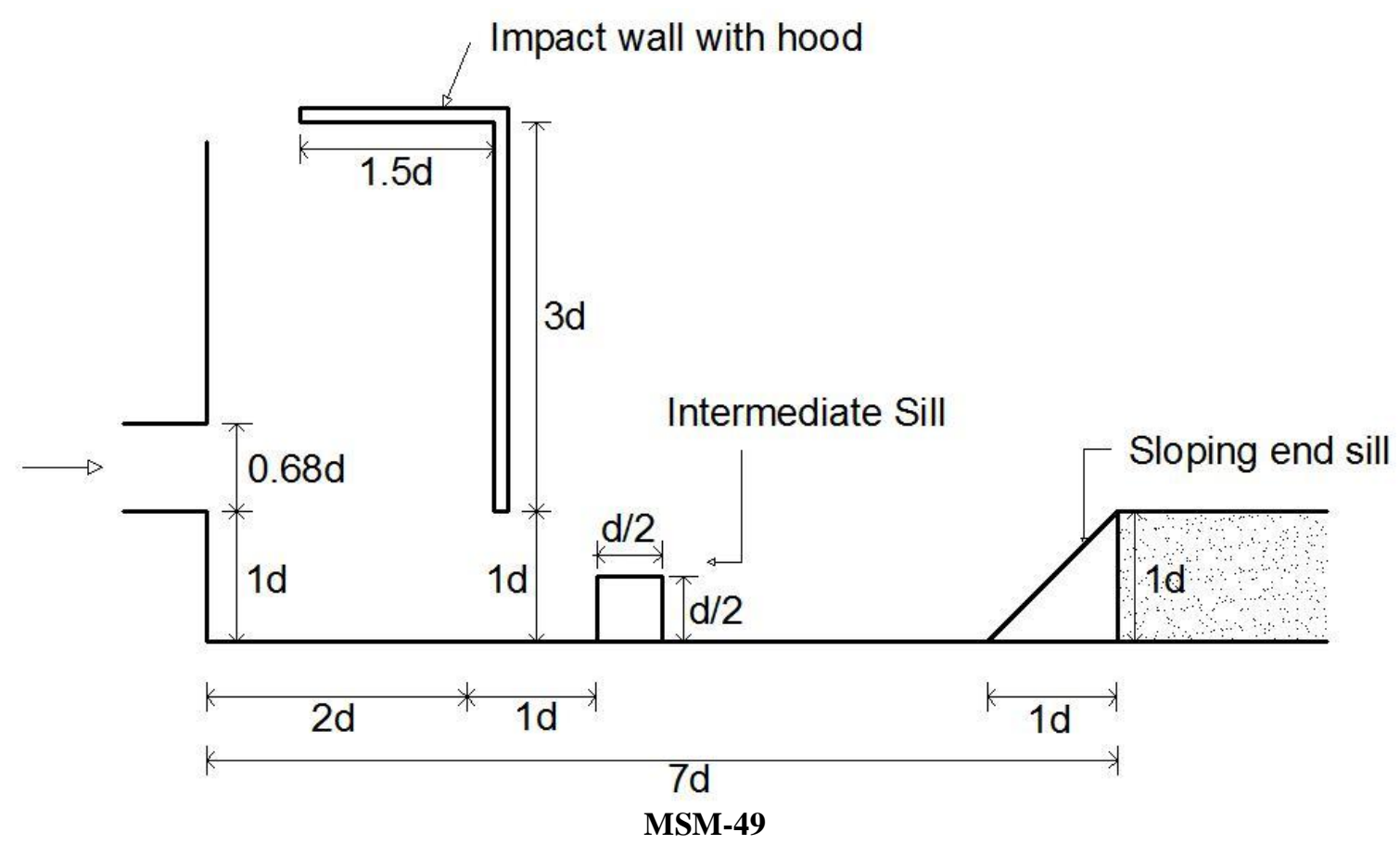

Fig 4 Models (MSM-48 to MSM-48) with Intermediate Sill along with Impact Wall and End Sill at Basin Length 7d

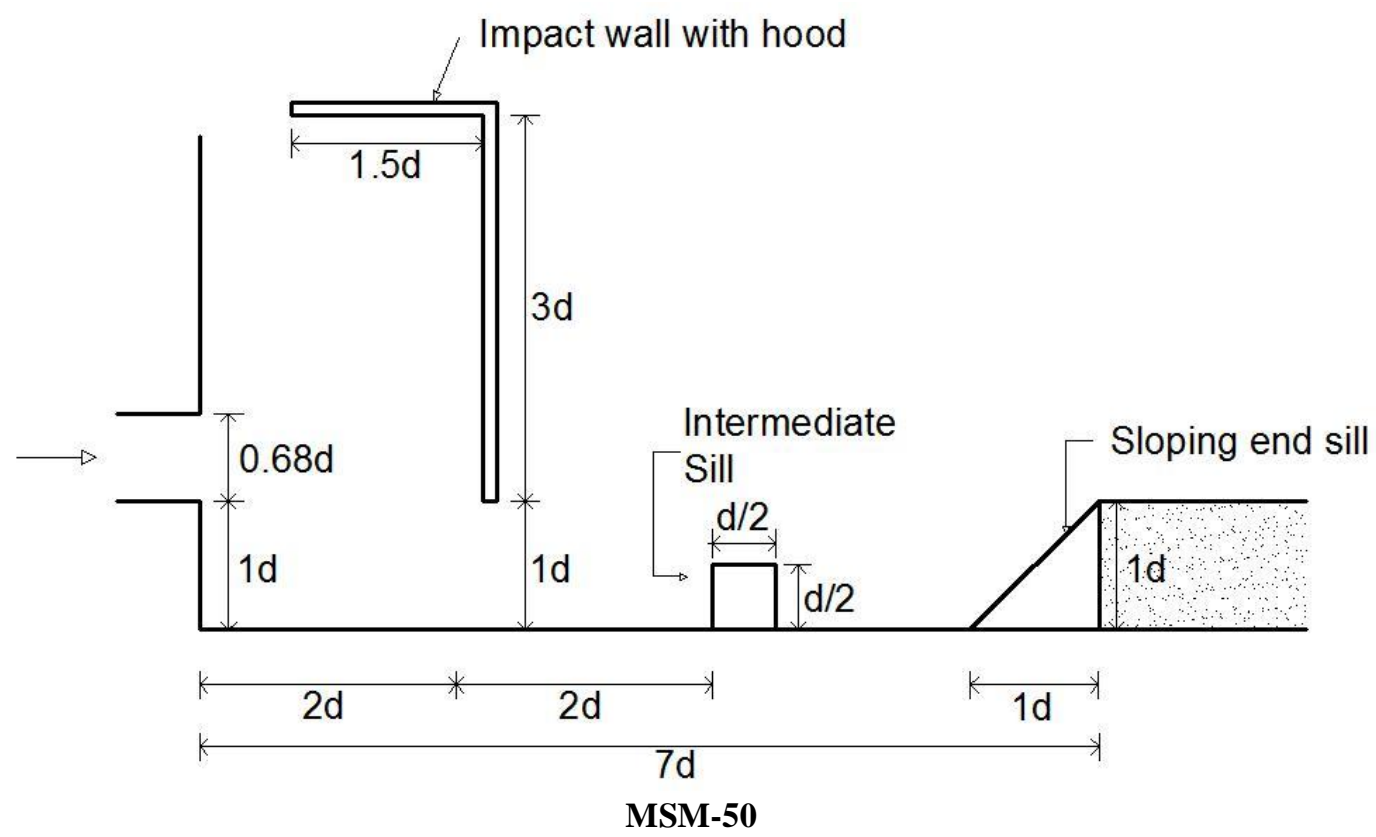




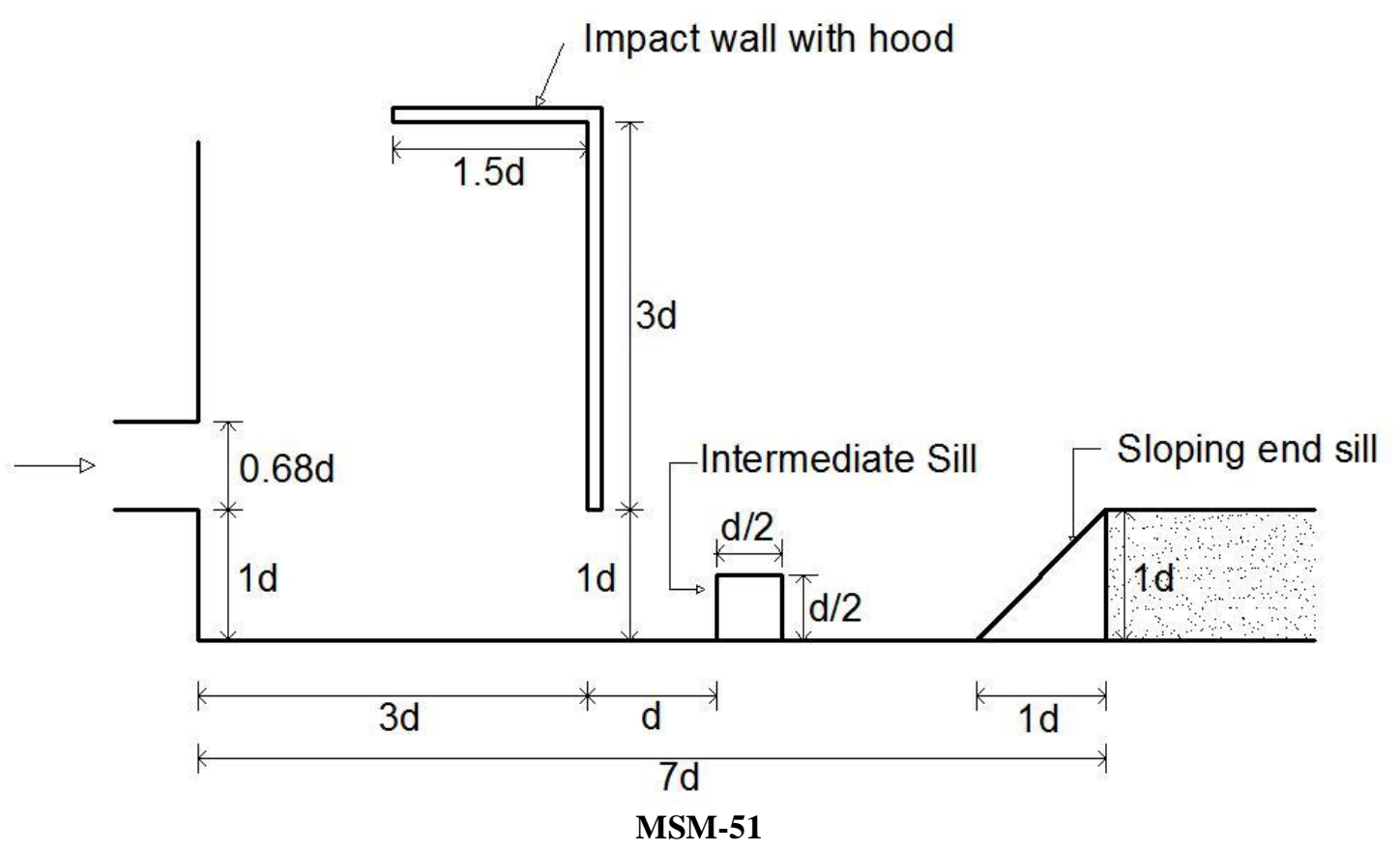

Fig 5 Models (MSM-5 to MSM-51) with Intermediate Sill along with Impact Wall and End Sill at Basin Length 7d

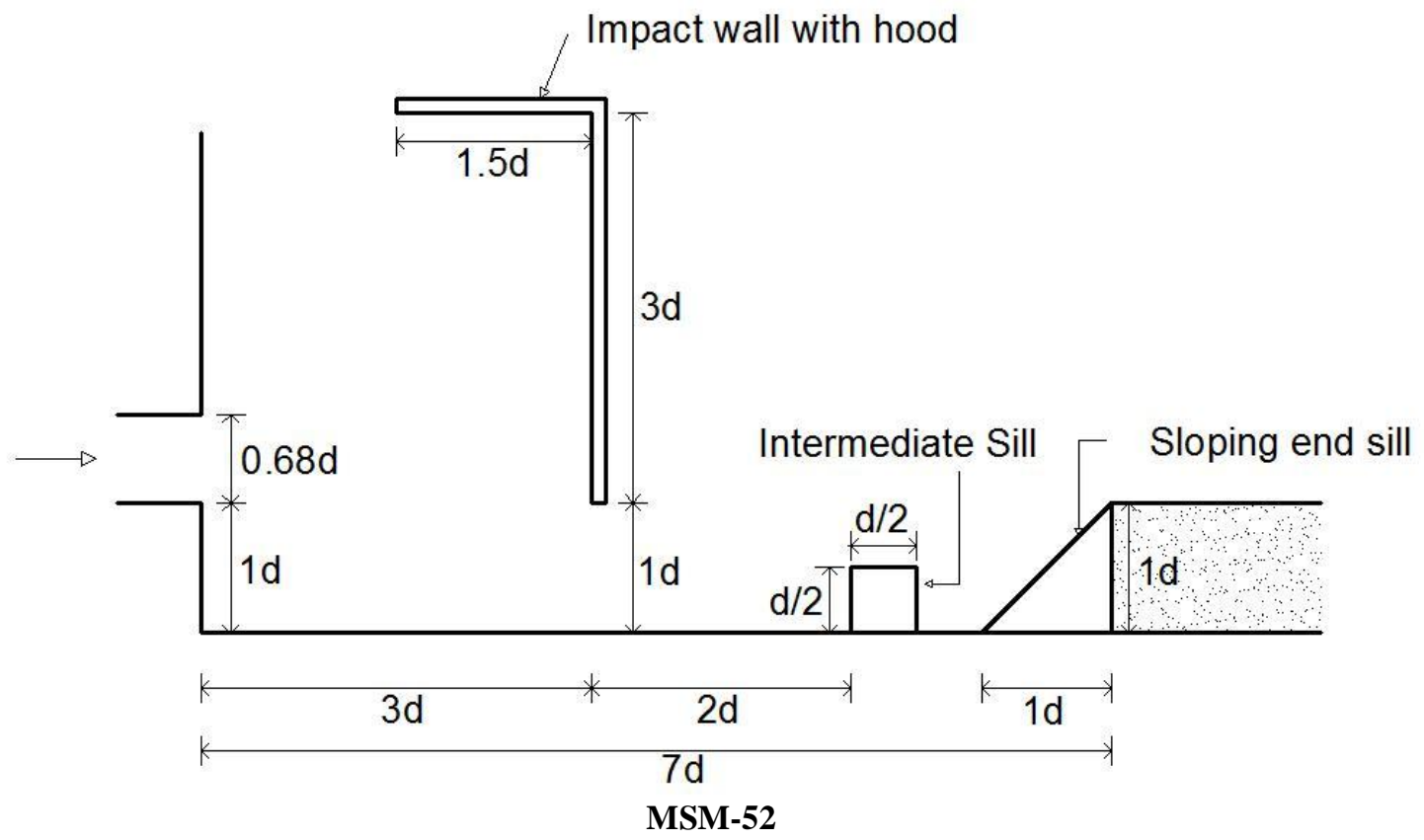




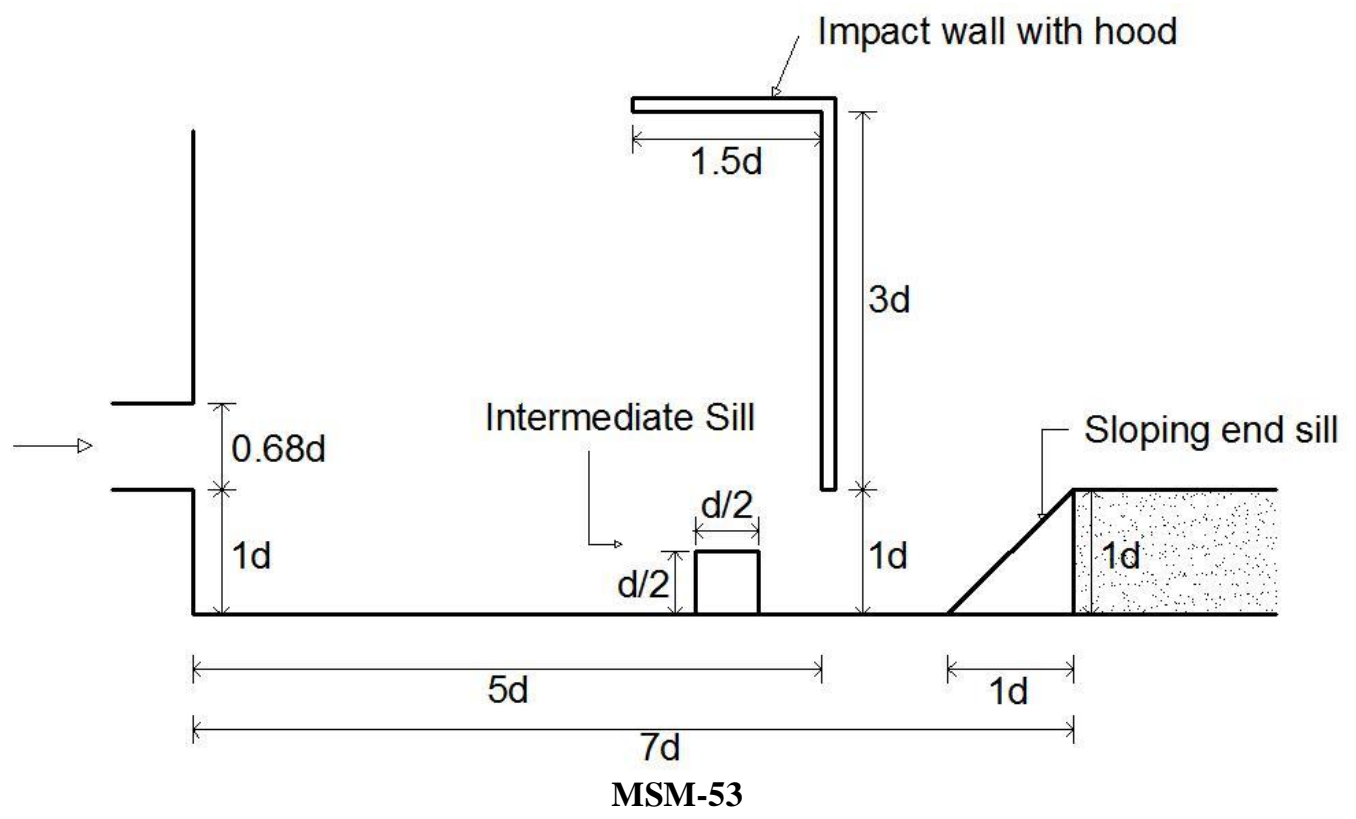

Fig 5.18 Models (MSM-52 to MSM-53) with Intermediate Sill along with Impact Wall and End Sill at Basin Length 7d

\section{RESULTS AND DISCUSSION}

As per USBR VI impact basin, impact wall of size $1 \mathrm{~d} \times$ $2.2 \mathrm{~d}$, placed at distance of $3 \mathrm{~d}$ from the exit of the pipe outlet. End sill of one d height with rectangular section having thickness $0.2 \mathrm{~d}$ was placed at distance of $8.4 \mathrm{~d}$ from the exit of pipe outlet. MSM-6 was tested, which is actually base model called as USBR-VI impact basin model developed by Bradley and Paterka(1957). PI values are computed and mentioned in Table 2. These values are 2.67, 2.63 and 3.42 for $\mathrm{Fr}=1.85,2.85$ and 3.85 respectively. To evolve efficient and economical hydraulic energy dissipating models, length of the basin was reduced to $7 \mathrm{~d}$. First of all, basin was evaluated by conducting the test runs for three Froude numbers in similar flow conditions with new impact wall located at $3 \mathrm{~d}$ along with sloping end sill fixed at $7 \mathrm{~d}$ and model was named asMSM-42.Performance indices were calculated as shown in Table2

After experimentation of stilling basin model testing for non circular pipe outlet, data analysis were performed for models MSM-46, MSM-47, MSM-48, MSM-49, MSM-50, MSM-51, MSM-52, and MSM-53 having intermediate square sill of size $d / 2 \times d / 2$ and impact wall of size $1.5 \mathrm{~d} \times$ 3d (IW4) at different locations along with triangular end sill fixed at $7 \mathrm{~d}$. From Table 2, it can be concluded that model MSM-46 having intermediate sill at $3 \mathrm{~d}$ and impact wall at $4 \mathrm{~d}$ performs better as it has higher values of performance index $(8.51,7.82 \& 9.45$ for $\mathrm{Fr}=1.85,2.85 \& 3.85$ respectively) as compared to other models. Intermediate sill of suitable height promotes the dissipation of energy in the basin by lifting high velocity filaments from the bed. No doubt performance of the stilling basin models improves with the inclusion of intermediate sill, which also confirms the findings of Negm (2007).
Table 2 Performance Index for Models Tested

\begin{tabular}{|l|l|l|l|l|}
\hline \multirow{2}{*}{$\begin{array}{l}\text { Sr. } \\
\text { NO. }\end{array}$} & \multirow{2}{*}{$\begin{array}{l}\text { nodel } \\
\text { name }\end{array}$} & $\begin{array}{l}\text { Fr } \\
1.85\end{array}$ & Fr $=2.85$ & Fr $=3.85$ \\
\cline { 3 - 5 } & & PI & PI & PI \\
\hline 2 & MSM-6 & 2.67 & 2.63 & 3.42 \\
\hline 3 & MSM-42 & 4.88 & 7.80 & 7.86 \\
\hline 4 & MSM-46 & $\mathbf{8 . 5 1}$ & $\mathbf{7 . 8 2}$ & $\mathbf{9 . 4 5}$ \\
\hline 5 & MSM-47 & 2.40 & 3.08 & 3.68 \\
\hline 6 & MSM-49 & 2.76 & 2.17 & 2.29 \\
\hline 7 & MSM-50 & 3.64 & 3.55 & 3.83 \\
\hline 8 & MSM-51 & 6.15 & 8.27 & 7.38 \\
\hline 9 & MSM-52 & 4.07 & 3.15 & 3.46 \\
\hline 10 & MSM-53 & 3.96 & 6.21 & 7.80 \\
\hline
\end{tabular}

\section{CONCLUSION}

An experimental study was carried out in the laboratory to study the role of square intermediate sill in the design of stilling basin model for non circular shaped pipe outlet with thirty test runs for Froude numbers $3.85,2.85$ and 1.85 . Based on the experimental results, it is found that the location of square sill and impact wall affect the performance of stilling basin model significantly due to change in the flow patterns. During the study it was found that the location of square intermediate sill and impact wall affects the flow conditions and ultimately scour pattern downstream of the stilling basin. This study also revealed that the higher values of performance indices indicate that the impact wall of size $1.5 \mathrm{dx} 3 \mathrm{~d}$ along with square sill located at $4 \mathrm{~d}$ and $3 \mathrm{~d}$ respectively dissipate more energy of flowing water and found to perform better for all flow conditions as compared to other models (showing lower values of performance indices) tested for non circular pipe outlet basin. This may be because by increasing the surface 
area, skin friction increase, by which dissipation of energy enhanced in the basin enabling the higher values of performance index. It is also found that by using only suitable impact wall at appropriate location with square sill efficiency of stilling basin models improved as compared to USBR VI model and also new model is shorter in length.

\section{REFERENCES}

[1] Bradley, J.N., Peterka, A. J. 1957, Hydraulic Design of Stilling Basins, Journal of A.S.C.E., Hydraulic Engg, , 83(5), 1401-1406.

[2] Fiala, J. R. and Maurice, L. A. 1961, Manifold Stilling Basins, Journal of A.S.C.E., Hydraulic Div.. 87(4), pp.55-81.

[3] Garde, R .J., Saraf, P.D., Dahigaonkar, D.J. 1986, Evolution of Design of Energy Dissipator for Pipe Outlets, J. of Irrigation \& Power, 41(3) ,145-154.

[4] Goel, A. 2008, Design of Stilling Basin for Circular Pipe Outlet. Canadian Journal of Civil Engineering, 35 (12), pp. 1365-1374.

[5] Keim, S. R. 1962, Contra Costa Energy Dissipator. Journal of A.S.C.E., Hydraulic Division, 3077 , March, , pp. 109-122.

[6] Negm, A.M. 2004, Effect of sill arrangement on maximum scour depth DS of abruptly enlarged stilling basins. Proc. of Int. Conf. Hydraulics of Dams and River Hydraulics, 26-28 April, Tehran, Iran.

[7] Tiwari, H.L., Goel, A. and Gahlot, V.K. 2011, Experimental Study of Sill Controlled Stilling Basins for Pipe Outlet, International Journal of Civil Engg. Research, 2(2), 107-117.

[8] Tiwari, H.L., Goel, A. and Gahlot, V.K. 2011, Experimental Study of effect of end sill on stilling basin performance, International Journal of Engg. Sci. and Technology, 3(4), 3134-3140.

[9] Tiwari, H.L, Gahlot, V.K. and Tiwari Seema, 2013, Reduction of Scour depth downstream of stilling basin, International Research Journal of Engineering Sciences. 2(7), pp.20-25.

[10] Tiwari, H.L.and Gahlot, V. K. 2012, Experiments on new Stilling basin for Pipe outlets, STM, AISECT University, 2(2), pp. 17-20.

[11] Tiwari, H.L. 2013, Design of Stilling Basin with Impact wall and End sill, International Research Journal of Resent Sciences, 2(3), pp.59-63.

[12] Tiwari, H.L. 2013, Analysis of Baffle wall gap in the Design of Stilling Basin Models, International Journal of Civil Engineering and Technology, .4( 4), pp.66-71.

[13] Tiwari, H.L. and Tiwari Seema 2013, Design of Stilling Basin Models with Intermesiate sill, Journal of Science, Technology and Management, 2( 4), pp.66-71.

[14] Tiwari, H.L, Gahlot, V.K. and Abhay Sharma, 2014, Effect of of Intermediate sill on the performance of stilling basin models, International Journal of Sc. Engineering \& Technology, 3(4), pp.414-417

[15] Tiwari, H.L.\& Goel A. 2015, Effect of impact wall on energy dissipation in stilling basin, KSCE Journal of Civil Engg, DOI, 10.1007/s12205-015-0292-5, 2015

[16] Vollmer, E., Khader, M.H.A. 1971, Counter Current Energy Dissipator for Conduit Outlets, International J. of Water Power, 23(7), 260-263.

[17] Verma, D.V.S, Goel, A. 2000, Stilling Basins for Outlets Using Wedge Shaped Splitter Blocks, ASCE Journal of Irrigation and Drainage Engineering 126 (3), 179-184.

[18] Verma, D.V.S., Goel, A. 2003, Development of Efficient stilling basins for Pipe Outlets, ASCE Journal of Irrigation and Drainage Eng..129(3), 194200. 